\title{
A Case of Parastomal Hernia with Isolated Abdominal Wall Metastasis Of Colorectal Cancer
}

\section{Kolorektal Kanserin İzole Abdominal Duvar Metastazı ile Birlikte Olan Bir Parastomal Herni Vakası}

\author{
Mehmet Özyıldız, Murat Burç Yazıcıoğlu, Hamdi Taner Turgut, Ali Çiftci, Osman Civil, Selim Yigit Yildiz \\ Kocaeli Derince Training and Research Hospital, Department of General Surgery, Kocaeli
}

Dergiye Ulaşma Tarihi: 13.02.2017 Dergiye Kabul Tarihi: 01.04.2017 Doi: 10.5505/aot.2017.93685

\section{ÖZET}

Kolorektal kanserin en yaygın uzak ve lokal metastazı sırasıyla karaciğer ve küçük pelvise olur. Kolorektal kanserin atipik lokalizasyonda izole metastazı, tanı anında ya da ameliyat sonrası izlem sürecinde görülebilir. Cerrahi teknik, kanserin evresi ve hastalığın doğal seyri gibi birden fazla faktör bu sürecin hayati bileşenlerini oluştursa bile bunların çoğunluğu tümör kolonizasyonu nedeniyle oluşur. Ancak tümör dökülmesine bağlı lokal nüksle nadiren karşılaşılır ve cerrahi teknik eksikliği en çok suçlanan nedendir.

72 yaşındaki kadın hastada da tübülövillöz adenoma zemininde gelişen orta derecede diferansiye distal rektal adenokarsinom (T1N0M0) için 2012 yılında geçirdiği APR (Abdominoperineal rezeksiyon) ameliyatından iki y1l sonra Parastomal herni tespit edildi. Parastomal herni onarımı için operasyona alınan hastada karın duvarının içinde şüpheli bir kitle palpe edildi. Kitle eksize edildi ve patolojik inceleme sonrası adenokarsinom olarak rapor edildi. Yeniden operasyona alınan hastaya kolostomi ile çevresindeki cildin ve $15 \mathrm{~cm}$ kolon segmentinin rezeksiyonunu içeren geniş rezeksiyon yapıldı. Biz, kolorektal kanserin izole metastazının izlem süresi boyunca görülebileceğini, bu nedenle atipik lokalizasyondaki herhangi bir kitlenin dikkatli değerlendirilmesi gerektiğini vurgulamayı amaçladık.

Anahtar kelimeler: kolorektal kanser, parastomal herni, adenokanser, izole batın duvarı metastazı, kolostomi

\begin{abstract}
The most common distant and local metastasis of colorectal cancer is to liver and small pelvis respectively. The isolated metastasis of colorectal cancer in the atypical localization can be seen at the time of diagnosis or at postoperative follow-up period. Multiple factors such as surgical technique, stage of cancer, and natural history of the disease are vital components of the process, however majority of them are due to tumor colonization. However local recurrence due to tumor exfoliation rarely encountered, indetermination of surgical technique is the most accused reason.

Parastomal hernia was detected in a 72 years old female patient two years after her APR (Abdominoperineal resection) operation in 2012 for moderately differentiated distal rectal adenocarcinoma (T1N0M0) that developed over tubulovillous adenoma. We found a suspicious mass within the abdominal wall closed to parastomal hernia in the operation. The mass was excised and reported as adenocarcinoma after pathological examination. Reoperation was planned and wide resection was performed with appropriate surgical margin including $15 \mathrm{~cm}$ of colon loops with skin of colostomy site. We aimed to emphasize that isolated metastasis of colorectal cancer can be seen during follow-up period so that any mass at atypical localization must be evaluated carefully.
\end{abstract}

Key words: Colorectal cancer, parastomal hernia, adenocarcinoma, isolated abdominal wall metastasis, colostomy

\section{Introduction}

Colorectal carcinoma is the most common malignancy of the gastrointestinal tract, has remained fairly constant over the past 20 years (1). Though the incidence is similar in men and women, it is the third most common cancer of male population however in female is the second most seen cancer around the world.
Colorectal cancer is diagnosed more than 1 million patients annually (2).

Twenty percent of colorectal cancer is presented with metastasis at initial diagnosis. Cancer cells spread by faces through the intestinal lumen as normal physiological transition (4), but for local and distant metastasis, transperitoneal spread, lymphatic spread, and hematogenous spread are the most used ways (3). Cancer of the colon and rectum are mostly metastases to regional lymph nodes, 
liver, lung, and peritoneum (4), it may present with unusual metastasis such as palm metastasis, scalp metastasis, epididymis and spermatic cord metastasis or isolated abdominal wall metastasis $(5,6)$. Rarely colorectal adenocarcinoma cells may be implanted into the anal fistula tract, in the hemorrhoidectomy scars or other various anal trauma sites (7).

Although reported incidence of abdominal wall metastasis of colorectal cancer was $0.5-1 \%$, autopsy studies have demonstrated that the actual incidence of metastasis to abdominal wall or wound raised up to $17 \%$ (8). There is general agreement that clinically obvious disease within the abdominal wall is often a sign of disseminated intraabdominal cancer (9).

In this study we presented a case of parastomal hernia with isolated abdominal wall metastasis after two years of abdominoperineal resection (APR) which was performed for moderately differentiated distal rectal adenocarcinoma that is developed on the base of tubulovillous adenoma.

\section{Case}

A 72 years old female patient who had an abdominoperineal resection (APR) operation in 2012 for moderately differentiated distal rectal adenocarcinoma (T1NOM0) was admitted to our polyclinic with swelling and pain around the stoma after 2 years. Physical examination revealed a parastomal hernia. Postoperative abdominal computed tomography (CT) scan was reported as normal in the first year. There was no sign of recurrence. But in the second year parastomal hernia was demonstrated in CT scan but no comment about the mass we found at operation. CEA and CA19-9 values were normal before first and second operation (2.4 $\mathrm{ng} / \mathrm{ml}, 7.59 \mathrm{ng} / \mathrm{ml}$ and $0.41 \mathrm{ng} / \mathrm{ml}, 5.65 \mathrm{ng} / \mathrm{ml}$ respectively). The posteroanterior (PA) chest $\mathrm{X}$-ray and abdominal ultrasonography were normal. There were no radiologic evidence of distant or local metastases. The patient was also consulted to oncology department before the repairment of parastomal hernia. The patient was planned for surgery with diagnosis of parastomal hernia, was given information about the surgical technique and written informed consent form was obtained. At operation a transverse incision was made from inferior of colostomy to identify the parastomal hernia but a $40 \times 30 \mathrm{~mm}$ mass was identified in the abdominal wall adjusted to hernia sac, fascia and distal colon. The mass was excised and reported as adenocarcinoma. When the patient's CT was reevaluated postoperatively, we recognized that metastatic mass was misdiagnosed and reported as only parastomal hernia (Figure 1). An extended resection was planned for the extension of resection. In the third operation systemic exploration was performed and found no sign of metastases. The fascia, peritoneum and $15 \mathrm{~cm}$ segment of proximal colon with skin of colostomy site was excised. Colostomy was revised from superior of first colostomy site. The defect in the abdominal wall was closed with dual mesh. Pathological examination of the last specimen reported as no sign of cancer metastasis with negative surgical margin. The patient was discharged and redirected to oncology for radiation and chemotherapy. In the follow up period of patient we found no sign of intraabdominal sign of recurrence in the first year of third operation. But unfortunately at the end of the second year we found some signs of intraabdominal metastasis of cancer.

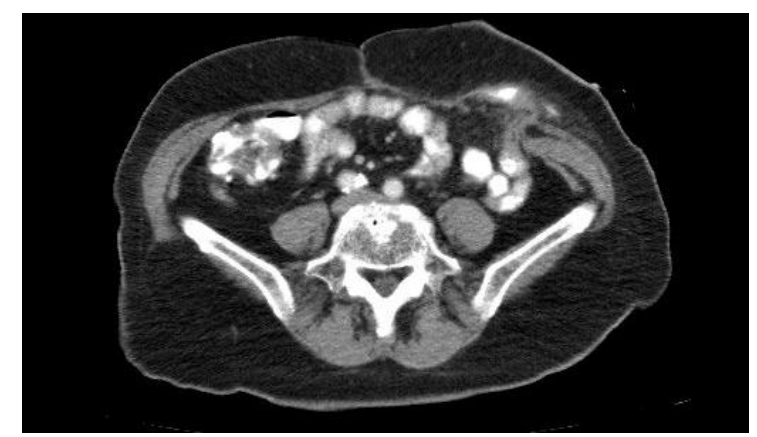

Figure 1: CT view of parastomal hernia and mass

\section{Discussion}

Lymphatic or hematogenous seeding, transperitoneal or direct metastasis are the ways of metastasis for colorectal cancer $(10,11)$. Colostomy site metastasis of adenocarcinoma especially after resection is rarely described entity in the literature. Spread of colorectal cancer by implantation was first reported by Charles Ryall in 1907 (12). Colorectal cancer spreading by implantation though rare, has been described in hemorrhoidectomy wounds, 
colonoscopic biopsy sites, laparoscopic port sites, site of perianal injury, introduction of EEA stapler during anterior resection, and Lonestar retractor insertion site after coloanal anastomosis (12).

Cutaneous metastasis can be seen in the old operation scars due to changes in the microscopic anatomy of the lymphatic channels, the changes in adhesion molecular profile or local immune response around the scar. These are eligible sites for metastasis of the tumor cells (13). Evidence from clinical and experimental studies suggests that surgical trauma may promote tumor metastasis to the abdominal wall (14). The importance of exfoliated cancer cells has been studied by several authors (15). A mechanism more likely responsible for abdominal wall metastasis is direct implantation of liberated cancer cells (13). It is thought that cancer cells may be present in the peritoneal cavity before the surgical procedure or may be exfoliated during operative manipulation (12). Trauma to a tissue has been known to enhance the growth of tumor cells either implanted into the peritoneal cavity or delivery to the tissues via the circulation (14). The more evidence of promoting tumor cells in the healing tissues of the laparotomy incision or the anastomosis were explained with hematogenous implantation (15). It is considered much less likely as an explanation, because the liver and lungs receive all of the venous drainage from the colon prior to the distribution to the rest of the body, it seems unlikely that the tumor would spread hematogenously to the abdominal wall without pulmonary or hepatic involvement (16). In clinical trials, the incidence of this entity have been reported as $0.5-1 \%$, but the autopsy studies have shown this ratio as $17 \%$ (4). Hughes et al. found that 16 of 1,603 patients undergoing curative resections had abdominal wall recurrence of their cancer, giving an incidence of 1 percent (17). In a prospective study, Reilly et al reported that wound recurrences were seen in 11 of 1711 patients $(0.6 \%)(18)$. Koea et al stated this ratio as $0.5 \%$ (11). This is our first case of detected abdominal metastasis in 280 colorectal cancer cases which were operated between 2009 and 2014 (0.36\%). Tumor recurrence due to the implantation sometimes occurs in the operating field, or in different places depending on the performed surgical procedure (19). There are many reports describing the implantation of tumor cells on the trocar sites during laparoscopic procedures (20). Vukasin et al have reported this ratio as $1.1 \%$ (10). Pezet et al have found cases of the abdominal wall metastasis after laparoscopic surgery (21). Koea et al reported that metastasis were detected in 31 of 6463 patients, sixteen patients developed tumor recurrence in a surgical incision which was used at the time of the primary operation (abdominal incision, colostomy site, or drain tract), 14 patients recurred in an abdominal wall site distant from the incision, and one patient, opened with a midline incision, recurred in a subcostal incision previously used for an open cholecystectomy (11). Hughes et al reported that only 13 ( 0.8 percent) of their series could be specifically isolated to a surgical incision; furthermore, only 11 ( 0.6 percent) were at the midline incision (18). In our cases patient had a midline incision but metastatic mass was found in stoma place with parastomal hernia. It is unclear how the tumor cells were implanted to abdominal wall in our case but we think that it was due to tumor cells seeding during first operation. In the literature it has been shown that despite the fact that there is often a relatively long interval between time of primary surgery and time of initial metastasis (2-49 months), prognosis with such abdominal wall metastatic disease is poor (14). In our study, the interval between time of primary surgery and abdominal wall metastatic disease was 24 months and metastasis detection time was compatible with literature. The patients who were operated and in follow-up period due to colorectal cancer, both physical examinations as well as investigations of abdominal wall (skin - subcutaneous - intramuscular), trocar insertion site should be done for newly determined mass in such areas may be sign of metastatic lesion. In addition to CEA, CA 19.9 monitoring, CT, MRI and PET-CT, or even trucut biopsy could be performed to detect the mass in the abdominal wall, are guidance in determining the appropriate treatment (4).

Optimal treatment for patients with abdominal wall recurrence is surgical excision with histologically clear margins. Complete surgical resection of localized recurrence within the abdominal wall, even when combined with en bloc resection of intra-abdominal viscera, is 
associated with a favorable outcome (11). This can lead to local control of the disease. Lymph node metastasis in the absence of abdominal wall eclipse does not change the prognosis, but the abdominal wall metastasis and intraabdominal recurrence, suggesting a poor prognosis in this case should be given systemic chemotherapy combined with surgical treatment $(22,23)$. Surgical treatment with systemic therapy shows a positive effect on long-term disease-free survival and overall survival. Radiotherapy and chemotherapy can be used as an adjuvant for providing local control (21).

\section{Conclusion}

Although many experimental studies indicate multiple factors, the exact etiology, although still unknown, was probably multifactorial (24). But management of tumor recurrence as new metastatic formations in the abdominal wall is one of the most difficult situations for surgeons. Though local recurrence is rarely seen due to exfoliation of tumor cells, it will reduce the effectiveness of surgical process. Therefore, it is suggested that meticulous surgical technique must be performed for a successful colon resection to reduce tumor cell exfoliation. It would also reduces the recurrence in the abdominal wall as a result of direct contamination (8). Metastatic disease should be kept in mind if a mass is detected within the abdominal wall (skin-subcutaneousintramuscular tissue) or trocar sites in the operated colorectal cancer patients, so that a careful investigation including physical examination and other diagnostic tests should be done. All patients must be informed about these kinds of conditions (4).

\section{Conflict of interest: None}

\section{References}

1. Dunn KMB, Rothenberger DA. Colon, Rectum, and Anus, In: Brunicardi FC (Ed). Schwartz's Principles of Surgery Tenth Edition. NY: McGraw-Hill; 2015. p.1175-1239

2. Jemal A, Bray F, Center MM, Ferlay J, Ward E, Forman D. Global cancer statistics.CA Cancer J Clin 2011;61:69-90 doi:10.3322/caac.20107. Epub $2011 \mathrm{Feb}$
3. Loktionov A. Cell exfoliation in the human colon: myth, reality and implications for colorectal cancer screening. Int J Cancer 2007;120:2281-9.

4. Cuhadır M, Ozdemir Y, Balta AZ, Sucullu I, Kara K, Narlı G. Isolated Anterior Abdominal Wall Metastasis of Rectal Adenocarcinoma. Journal of Diseases of the Colon and Rectum 2015;25:58-62

5. Siegel RL, Miller KD, Jemal A. Cancer statistics, 2015. CA Cancer J Clin 2015; 65:5-29. doi: 10.3322/caac.21254. Epub 2015 Jan 5.

6. Karagoz B, Bilgi O, Kucukodaci Z, et al. Metastasis to the epdidymis and spermatic cord from colon adenocarcinoma: a case report. Anatol J clin Investig 2008; 2: 130-31

7. Balta AZ, Sucullu I, Ozdemir, Dandin O. A rare clinical manifestation of rectal adenocarcinoma and synchronous scalp metastasis: A case report. Ulus Cerrahi Derg 2013; 29: 197-9. doi:10.5152/UCD.2013.16. eCollection 2013.

8. Hsu T-C, I-Lin L. Implantation of adenocarcinoma on hemorrhoidectomy wound. Int J Colorectal Dis 2007; 22: 1407-1408.

9. http://www.saglik.gov.tr/TR/dosya/1-4481/h/kanseristatikleri.x1s\&ved $=0 \mathrm{CCkQFjAE \& usg=AFQjCNG9}$ iHjfo_sO1cPb0Du3YTZHVxwG5g\&sig2=E14sILn -3jHdDX CRXmwag

10. Vukasin P, Ortega AE, Greene FL, Steele GD, Simons AJ, Anthone GJ, et al. Wound recurrence following laparoscopic colon cancer resection. Results of the American Society of Colon and Rectal Surgeons Laparoscopic Registry. Dis Colon Rectum. 1996 Oct; 39 (10 Suppl): S20-3.

11. Koea JB, Lanouette N, Paty PB, Guillem JG, Cohen AM. Abdominal wall recurrence after colorectal resection for cancer. Dis Colon Rectum 2000; 43:628-32.

12. Gomes RM, Kumar RK, Desouza A, Saklani A. Implantation metastasis from adenocarcinoma of the sigmoid colon into a perianal fistula: a case report. Ann Gastroenterol 2014; 27:276-279.

13. Skipper D, Jeffrey MJ, Cooper AJ, Alexander P, Taylor I. Enhanced growth of tumour cells in healing colonic anastomoses and laparotomy wounds. Int J Colorectal Dis 1989; 4:172-7.

14. Kanellos I, Demetriades H, Zintzaras E, Mandrali A, Mantzoros I, Betsis D. Incidence and prognostic value of positive peritoneal cytology in colorectal cancer. DisColon Rectum 2003; 46: 535-539

15. Demetriades H, Kanellos I, Vasiliadis $\mathrm{K}$, Christoforidis E, Betsis D. Abdominal wall metastasis following treatment of rectal cancer. Tech Coloproctol 2004; 8 Suppl 1: s101-3.

16. Murthy SM, Goldschmidt RA, Rao LN, Ammirati M, Buchmann T, Scanlon EF. The influence of surgical trauma on experimental metastasis. Cancer 1989; 64: 2035-44.

17. Fusco MA, Paluzzi MW. Abdominal wall recurrence after laparoscopic-assisted colectomy for adenocarcinoma of the colon. Report of a case. Dis Colon Rectum 1993; 36: 858-61.

18. Hughes ES, McDermott FT, Polglase AL, Johnson WR. Tumor recurrence in the abdominal wall scar tissue after large-bowel cancer surgery. Dis Colon Rectum 1983; 26: 571-572 
19. Reilly WT, Nelson H, Schroeder G, Wieand HS, Bolton J, O'Connell MJ. Wound recurrence following conventional treatment of colorectal cancer. A rare but perhaps underestimated problem. Dis Colon Rectum 1996; 39: 200-7.

20. Enker WE. Potency, cure, and local control in the operative treatment of rectal cancer. Arch Surg 1992; 127: 1396-401

21. Wexner SD, Cohen SM. Port site metastases after laparoscopic colorectal surgery for cure of malignancy. Br J Surg 1995; 82: 295-8.

22. Pezet D, Fondrinier E, Rotman N, Guy L, Lemesle $\mathrm{P}$, Lointier P, et al. Parietal seeding of carcinoma of the gallbladder after laparoscopic cholecystectomy. Br J Surg 1992; 79: 230.

23. Ledesma EJ, Tseng M, Mittelman A. Surgical treatment of isolated abdominal wall metastasis in colorectal cancer. Cancer 1982; 50: 1884-7.

24. Balli JE, Franklin ME, Almeida JA, Glass JL, Diaz JA, Reymond M. How to prevent port-site metastases in laparoscopic colorectal surgery. Surg Endosc 2000; 14:1034-6.

doi:10.1007/s004640000223 